\title{
Holistics Paradigm in the Development of Emotional Intelligence (EQ) and Spiritual Intelligence (SQ)
}

\author{
Zubaedi \\ UIN Bengkulu \\ Bengkulu, Indonesia \\ zubaedi1969@gmail.com
}

\begin{abstract}
This article discusses the holistic paradigm in the development of EQ, and SQ. This article is written on the assumption that the perfect man (Insan kamil) is a human being that develops all the potential or intelligence, both physical potential, spiritual, and intellect (IQ, EQ, and SQ). This study concludes that one's success is determined not only by the ability of the brain and mere thought (IQ), but in reality is determined also by the dimension of emotional intelligence (EQ), and spiritual intelligence (SQ). This of course requires our new awareness to apply education in a balanced way, taking into account and giving equal emphasis to IQ, EQ, and SQ.
\end{abstract}

\section{Keywords—human skill and competences; neurosains}

\section{INTRODUCTION}

Philosophically, the essence of education is to form a perfect human or kamil human. In a psychological perspective, the perfect man (man kamil) is a human being who develops all his potential or intelligence, both physical, spiritual, and intellectual potential (IQ, EQ, and SQ). Theoretically there is a common perception between psychology, education, and neuroscience so that all three can be integrated. The concept of the perfect man (man kamil) who has the elements of physical, spiritual, and intellect is the same as the psychological concept of cognitive, affective, and psychomotor.

Education is ideally required to develop the human fithrah as the Caliph on this earth. In carrying out the mandate, humans have the ability called Human Skill and Competences (HSC), which in HSC there are 4 levels of intelligence possessed by humans, among them are: IQ, EQ, SQ, and AQ [1].

A reflection can be argued that someone who has a high IQ but a low EQ tends to experience greater failure compared to someone who's IQ is average but has a high EQ. This means that EQ ownership or exercise is a very important factor in the success of a career for someone in the world of work. In line with Coleman's stated proportion: $85 \%$ EQ and 15\% IQ [2].

Therefore, the task of educational institutions is to develop the totality of this intelligence by combining the dimensions of neuroscience, education, and psychology. Neuroscience is specified in the rational brain (IQ), the emotional brain (EQ), and the spiritual brain (SQ). Education is specified in physical, spiritual, and intellectual development. Psychology is specified on cognitive, affective, and psychomotoric. All these elements are combined in an eclectic unity between philosophy, theory, and implementation. This means neuroscience education (neurosciences in learning, not only theoretical concepts that are still philosophical, but can be applied by teachers in a practical-empirical.) Thus, in the perspective of Islam, the essence of education is to print kamil our insan kamil Insan kamil is organized in various elements, , spiritual, and intellectual, nafs, qolb, aql, IQ / EQ / SQ; cognitive, affective, and psychomotor [3].

Educational institutions when developing IQ in the form of knowledge and skills, simultaneously required to develop the EQ as well as possible. Given the process of improving the ability of IQ and EQ need to utilize the deepest human conscience then we must also build SQ which is a reflection of our relationship with the Creator/Allah SWT. Through SQ, we are trained to use sincerity to further sharpen and solidify what we can do spiritually. With a blend of IQ, EQ and SQ this makes the soul of a person develops intact.

Fatwa argues that education must have a "spirit" that develops wise values, and leads to intellectual intelligence (IQ), emotional intelligence (EQ), and spiritual intelligence (SQ). EQ and SQ are very instrumental in supporting one's success in the struggle of his life. Wisdom to control emotions will support the workings of reason and intellect. EQ will build motivation, empathy, the ability to understand yourself and others, the nature of sympathetic, solidarity, and high social interaction. While SQ will guide a clear conscience that leads to lofty passion, dare to face life with optimism, creative, flexible, and visionary, and provide moral strength, provide certainty answers about something good and bad, and responsible for life and environment. All will realize the ability to transform barriers into opportunities, and resilience in the face of life challenges, known as adversity quotient (AQ) [4].

This phenomenon has awakened the experts that one's success is not only determined by the ability of the brain and the power of thought alone, even more determined by emotional intelligence (EQ), and spiritual intelligence (SQ). Surely there is something wrong in the pattern of human resource development so far, that is too put forward IQ, ignoring the EQ, and SQ. Therefore such conditions are timed to end, where education should be applied in a balanced way, taking into account and giving equal emphasis to IQ, EQ, and SQ. 


\section{The Stages of EQ DEVELOPMENT}

Educate the EQ start by building the power of the soul. This is because the soul becomes the power that enlivens and activates the body. According to one Muslim philosopher, Ibn Maskwaih, humans are created with potent psychic powers and they grow naturally. The initial psychic forces of the soul are biological in the form of the tendency of syahwaniyah such as eating, drinking and sex to develop the physical. These biological demands continue to evolve into various tendencies of desire. Followed by the emergence of the power of imagination generated from the senses. Thereafter comes the power of the ghodabiyah which becomes the willpower to act over the obstacles or to satisfy the desire. If he fails to cope alone, weep the child, or he asks for help from his parents. After that the birth of the power tamyiz (can reasoning) characterized by the development of intellect to consider the behavior typical of human. This happens little by little until it reaches a developmental level called aqil (L'enfant fait). These forces are diverse, partially capable of encouraging the emergence of other forces until they reach the ultimate goal of the development of the human mind, called al-khair al-mutlaq, an absolute virtue that man desires because of his existence as a human being [5].

By growing EQ directly will give birth to a healthy mentality. Mental health refers to Zakiah Daradjat's opinion indicated by the realization of the true harmony between the psychic functions and the creation of self-adaptation between man and himself and the environment based on faith and piety, and aims to achieve a meaningful and happy life purpose in the world and [6].

According to Lawrence E. Shapiro, EQ can be taught in ways to love the child, not just and fulfill all his requests. Affirmative affection means providing the best situation for the child's emotional development and supporting it in a way that is clearly recognizable to the child. This affection means actively involved in the emotional life of the child, among others, can be done through telling a child who contains a message of affection. According to Abdul Aziz Abdul Majid, the story is in the first position in educating ethics to children. Children tend to like and enjoy it, both in terms of ideas, imagination, and events. Rebuking, preparing mentally for something to happen, or building discipline and character, is very well done through the story. Because the intended person can hear and receive it well. The unconscious child always needs and feels thirsty for the story. While behind the story, parents and teachers can instill empathy, conscience, selfcontrol, kindness, respect, tolerance and justice to children without children feeling patronized and required [7].

Through the story, the child will easily understand what traits, figures, and actions are good and which are bad. Stories can play a role in the process of forming a child's character. Even according to educator character Seto Mulyadi children, the story is very important for children to spur they have a fighting spirit in the face of various difficulties of life [8].

Parents can stimulate the emergence of EQ children in various ways on various occasions. Abundant stimulation can help the child to learn more about himself. In general there are some steps that can be done by parents in developing children's emotional intelligence. First, exchange ideas with the child about his experience when he feels happy, angry, sad, shocked, disappointed, and so on. Second, discuss with the child about his or her experience of observing others who are experiencing feelings of pleasure, anger, sadness, shock, disappointment, and so on. Third, play a drama or role, read a fairy tale, watch a clip or a movie and ask the child to determine the emotional state of the character. Fourth, help the child in planning. The child can make anticipation of events that will be faced, for example when he will go to school. Fifth, play with the child in order to grow his ability to name the emotions he is feeling. Sixth, discuss with the child to realize the similarities and differences that underlie the occurrence of these emotions. For example, understand the differences and similarities between likes and love, feel annoyed and feel angry, and so forth. Seventh, help children understand about the relationship between emotions with a particular situation. For example, the relationship between sadness and loss of toys is preferred.

Eighth, parents teach children about emotional separation by behavior. For example, smiling in public despite being sad. The child develops strategies that can be used to control an emotional reaction. For example, counting to 10 while being angry or giving paper and crayons to the child and asking him to describe his feelings in the paper.

Ninth, choose an activity that is identical to a particular emotion, such as dancing or pleasure. Tenth, choosing friends who can help the child maintain a positive view of himself. Eleventh, motivate yourself to nurture pleasant emotions by remembering fun experiences and doing fun activities, such as reading books, singing, and dancing. The twelve, involving the child with as many activities as possible with other people and the fun for him, such as extracurricular activities, summer camp, and others. Thirteen, ask the child to tell the experience he had experienced for 1 day, and what he learned from the experience [9].

The ability of emotional intelligence, must be true and should always be trained. This is actually one of the expected outputs arising from fasting. Fasting is a great training that the method is directly given by Allah SWT This is a form of effective training to train emotional control and build emotional intelligence (EQ). Many Muslims have not realized the meaning and great purpose behind the fast. To understand the meaning of fasting, it must be understood in advance that fasting is the unity of the whole series of Islamic pillars, comprehensive, should not be separated. Like a tree, its root is a shahada, a pillar or a shaft is a prayer. Fasting is cleansing the names that are in the tree, with the power of nature that is in it. So that comes out the leaves and fruits are healthy, the real goodness that becomes the product. All that happens only through a regular process of production or regular motion.

In addition, children can also independently participate in trainings or personality trainings that are currently held by many psychological institutions. All these efforts are taken to form a child to have emotional intelligence characterized by good emotional control. In short, he can control stress. This issue is not easy to do, but requires intensive training. 


\section{THE EFFORTS IN SQ DEVELOPMENT}

After developing emotional intelligence (EQ), educators need to equip it with the development of spiritual intelligence (SQ). Our educational world in the future is required to be more committed in educating this SQ. Important breakthroughs are needed in reconstructing the curriculum and learning process in our educational institutions that provide a place in strengthening SQ. It is not enough if we just give the main mandate (main task) teaches this dimension only on religious education.

Moreover, it is realized that the pattern of religious learning is still biased cognitive, thick with theoretical approach, verbalist and monologue. Religious education is expected to provide solutions to the problems of life today, it turns out to be only the teaching of "fiqih", and is understood as a ritual approach only, resulting in the separation between world life and the hereafter. The pillars of Faith and the pillars of Islam are taught to the students so far as to be limited in the form of rote in the left brain, without being understood [10].

Zohar and Marshall provide solutions to improve spiritual intelligence with six steps. First, the assignment step. This move avoids humans from ugly prejudices, narrow minds, lack of imagination and lack of motivation. Through this step of assignment is expected to grow harmonious cooperation and give each other mutual thoughts. Second, parenting, this move prevents people from being opportunistic and pragmatic. It teaches humans how to listen to the opinions of others well. Third, the step of knowledge, teaches not to be scientific or also distanced himself from discussing trivial matters that are not his business [11].

Fourth, personal change step. This step teaches how to be intelligent a spiritual step by awakening in the self that conscience is everything. He will never have any doubts in doing positive things. When this step is taken, there will be no terms of promises of proof or promise even kept.

Fifth, the step of creating brotherhood. This step teaches how to do justice and respect to the enemy though. Sixth, a devoted leadership step. This step teaches that how to avoid harnessing power for its own ends and other evil goals. Thus will be born a sincere devotion.

Learning about SQ, of course, is not possible through mere theories, because it involves understanding, appreciation and practice of living meaning. Therefore, it is in need of constant practice methods. In the shadows the authors include the nuances of the meaning of life as the goal to be achieved in classroom learning will not be realized in a particular subject, but will be implied in every subject taught to the students. This material will also not be included as part of the sub-discussion in the class. Learning about the meaning of life will be introduced, taught, and trained through everyday learning methods in the classroom. That is, the dynamics of life in the classroom will be more oriented to spiritual intelligence in which every citizen of the class has a deep appreciation of the meaning of everything for him.

In general, the internalization efforts of spiritual intelligence conducted by a nation or company is through upgrading, sermons, lectures, or training. Billions of funds have been issued by a nation or thousands of companies to seek to change the attitude and character of the nation or its employees. The most common impact of these activities is the increased self-confidence of the participants, at least temporarily. After that, they will return to their habits as before the upgrading or training.

Japan has a different mechanism in instilling spiritual intelligence to its people. To form the character required a habit that is done repeatedly, consistently, and continuous, called behaviorism method. This mechanism is called Repetitive Magic Power (RMP). This mechanism is generally used almost by all companies or organizations in Japan. The Japanese karateka for example, they are asked to shout, "I'm champion!", to the count to 100 before they practice. The same way is done by Matsushita companies around the world [4].

Every day after Taisho's morning apple and gymnastics, all Masushita employees will read over and over the following words: 1) Worship and Giving, 2) Honest and Trustworthy, 3) Fair, 4) Cooperation or Unity, 5) Struggle or Be True, 6) Friendly and Loving, and 7) Thankful and Thankful. Tradition and Japanese culture that has been accustomed and hereditary instill spiritual intelligence with RMP method, making Japan as a nation that has a noble personality. Through Japanese companies scattered throughout the world, the Japanese have played a role in globalizing culture by changing the personality of other nations.

This spiritual intelligence can be regarded as the highest moral stage, which will give birth to the attitude of addiction to do good. Like Johnny the Appleseed who has planted an apple tree only for the benefit of others, without thinking that he will take shelter in leaf shade, or picking the fruit. He did it because he simply felt "addicted" to doing it. The story, Jonathan Chapman who was born in 1774 in Boston, often wandering with bags of bags containing apple seeds to be distributed wherever he went. He intentionally planted an apple tree so that the other travelers (people on the way) can pick up fresh apples and thirsty bidders, and rest under the shade of an apple tree. Reportedly there are tens of thousands of apple trees that have been planted in Ohio and Indiana in the United States [12].

In addition to apple trees, he also planted a lot of medicinal trees in empty lands, so the medicinal plants stretched out to look like a green carpet. Anyone can pick it. He is indeed very well known and loved by anyone who knows him. Although he has died, the apple trees he planted continue to provide tremendous benefits to the surrounding community. Imagine, if one apple consists of 5 seeds, while each seed can produce apple trees that will bear thousands of apples, then how many million apple trees that grow next from the seeds planted Johnny? Then, no wonder the name Johnny became a legend that continues to be known all the time. There are so many people who want to help others unconditionally because they are inspired by the story of Johnny the Appleseed [12].

Lessons that teach spiritual intelligence indicators [13]. Can be presented as follows: 
TABLE I. TEACH SPIRITUAL INTELLIGENCE INDICATORS

\begin{tabular}{|c|c|}
\hline $\begin{array}{l}\text { Indicators of } \\
\text { Spiritual } \\
\text { Intelligence }\end{array}$ & Implications in Learning \\
\hline Flexibility & $\begin{array}{l}\text { Do not base your learning on an absolute } \\
\text { source so that students are not accustomed to } \\
\text { being focused on just one information as a } \\
\text { source of truth } \\
\text { Encourage students to find as many ways as } \\
\text { possible to achieve a goal, for example in } \\
\text { answering questions } \\
\text { Giving freedom to cast opinions, impressions, } \\
\text { or feelings without directly giving an } \\
\text { assessment of the right and wrong }\end{array}$ \\
\hline Self Awareness & $\begin{array}{l}\text { Encourage students to become fully involved } \\
\text { in learning } \\
\text { Not make the distance between learning } \\
\text { materials with self and student life. } \\
\text { Encourage the student to share his thoughts } \\
\text { and feelings with regard to the implications of } \\
\text { the material being learned in his or her state. }\end{array}$ \\
\hline $\begin{array}{l}\text { Able to Face \& Use } \\
\text { Suffering or Pain }\end{array}$ & $\begin{array}{l}\text { Bringing themes of suffering in discussions \& } \\
\text { talks in learning activities. } \\
\text { Uncover the experience of pain in learning } \\
\text { activities and find ways to deal with it } \\
\text { Give examples of relatively difficult cases or } \\
\text { problems and encourage students to solve } \\
\text { them }\end{array}$ \\
\hline $\begin{array}{lll}\text { Inspired } & \text { Vision } \quad \& \\
\text { Values } & & \end{array}$ & $\begin{array}{l}\text { Invite students to start activities with a goal } \\
\text { and focus all activities on those goals } \\
\text { Begin each learning activity by revealing its } \\
\text { purpose and demonstrating systematic steps to } \\
\text { achieve that goal. } \\
\text { Evaluate the objectives at the end of each } \\
\text { learning activity to see whether the } \\
\text { implementation of learning activities is in line } \\
\text { with the objectives. }\end{array}$ \\
\hline $\begin{array}{l}\text { Reluctant to cause } \\
\text { unnecessary losses }\end{array}$ & $\begin{array}{l}\text { Invite to have a habit of thinking broadly } \\
\text { before starting something } \\
\text { Encourage the students to be thorough and } \\
\text { careful in every action } \\
\text { Familiarize yourself to analyze the advantages } \\
\& \text { disadvantages of each material (theory) that } \\
\text { is being taught }\end{array}$ \\
\hline $\begin{array}{l}\text { Seeing the } \\
\text { relationship between } \\
\text { things }\end{array}$ & $\begin{array}{l}\text { Always invite students to link learning } \\
\text { materials with themselves and various aspects } \\
\text { of life } \\
\text { Familiarize to find the relationship between } \\
\text { one material with other material or material } \\
\text { taught today with the material previously } \\
\text { taught. }\end{array}$ \\
\hline $\begin{array}{l}\text { Looking for the } \\
\text { fundamental reasons }\end{array}$ & $\begin{array}{l}\text { Familiarize students to ask everything that } \\
\text { happens during the learning process } \\
\text { Developing a question and answer culture } \\
\text { within the learning process } \\
\text { Begin each teaching and learning activity with } \\
\text { questions about the material to be learned. }\end{array}$ \\
\hline Independent & $\begin{array}{l}\text { Gives tasks done individually } \\
\text { Encourage each student to express the ideas in } \\
\text { his mind and be ready to account for them in } \\
\text { the event of a debate. }\end{array}$ \\
\hline
\end{tabular}

Operationally, the development of the two intelligences (EQ, and SQ) needs to be implemented holistically. This is because between the four intelligences have interconnectedness. In this context, we can learn in Japan in integrating IQ with EQ. Empirically, Japan has succeeded in accelerating the progress of its people so as to place itself as a developed country that rely on human resources (HR), not natural resources (SDA). Japan has made a paradigm shift in education since 1988. This shows that there has also been concern in Japan about the quality of education, especially in the era of facing the climate of globalization. There is anxiety in educational experts and parents in Japan that the educational system at that time has shifted to a pattern "only concerned with cognitive aspects only," which is characterized by increasingly high rates of stress in schoolchildren and an increased rate of suicide. As a result of the reform process that began in 1988, in 2002 the Ministry of Education of Japan finally explicitly emphasized the importance of implementing the concept of holistic education, an integrated learning system that involves "hands-heart-head, doing- feeling-thinking, bodymind-soul "(hand-heart-brain, do-feel-think, body-mind-soul) [14].

Similar pattern is also practiced in Singapore. In this lion country, since 2005 has implemented an education system called "holistic education" which is developing the child morally. Intellectually, physically, socially and aesthetically. Indonesia Heritage Foundation (IHF) also has been developing since 2000 a model of "Character Based Holistic Education" in anticipation of rapid change in the future, so that Indonesian children as early as possible be prepared to be able to live in the future. This model focuses on the formation of students' character and creativity through the development of all human dimensions holistically (academic, creativity, social, emotional, psychomotor, and spiritual) [15].

Therefore our education needs to be oriented in building the integrity of the three intelligences (IQ, EQ and SQ) proportionately. This is based on the consideration that a person if have all three will deliver a successful life in the world and in akherat. To facilitate understanding, the position of each intelligence in a Muslim can be described through prayer. If someone has an IQ actualized with the ability to perform the prayers according to fiqh rules. He fulfills the requirements, doing the correct qauliyyah or fi'liyyah, and avoids the nullifying case. This intelligence is regarded as the first level, it needs to be continued with the second level of emotional intelligence that is actualized with the ability to do prayer solemnly, sincerely and solely seeking God's blessings. Ends with the third level as the impact or influence of prayer from the social side as evidence of spiritual intelligence. This is actualized by his ability to apply the social values that prayer implies in everyday life. It is proved that after the prayer, his speech is more polite, generous, easy to do good and other things in the eyes of society as charity of virtue.

Another example, for example when we remembrance. Intellectual intelligence is characterized by the recitation of his dhikr which is spoken correctly and eloquently. His emotional intelligence is characterized by dhikr with wholeheartedly, khusu 'and remorseful of his sins so that tearfully unconsciously. Ultimately, having a spiritual intelligence is characterized by everyday behavior that reflects a person who behaves in a moral manner better than ever before as an impact of possession of his emotional intelligence. 


\section{CONCLUSION}

Educational institutions in developing IQ in the form of knowledge and skills required simultaneously are required to develop the best EQ. Given the process of improving the ability of IQ and EQ need to utilize the deepest human conscience then we must also build SQ which is a reflection of our relationship with the Creator/Allah SWT. Through SQ, we are trained to use sincerity to further sharpen and solidify what we can do spiritually. With a blend of IQ, EQ and SQ this makes the soul of a person develops intact. In life, these three intelligences can lead a person to success in the face of all good circumstances that are pleasant or sad.

\section{REFERENCES}

[1] R.M. Angkita, "Pengembangan Sumber Daya Insani Berbasis Islami Berdasarkan Keseimbangan IQ, EQ, SQ dan AQ," dalam Rasail, Jurnal Pemikiran Islam, Yogyakarta: Prodi Perbankan Syari'ah STEBI AlMuhsin Yogyakarta, vol. 2, no. 1, 2015.

[2] Ramli, "Kreativitas Anak Dapat Dilihat Dari Berbagai Indikator" dalam ramli mpd. blogspot.co.id, Dipublikasikan 30 September 2010. http://ramlimpd. Blog spot. co.id/2010/09/ kreativitas-anak-dapatdilihat-dari.html

[3] Suyadi, Teori Pembelajaran Anak Usia Dini dalam Kajian Neurosains. Bandung: PT Remaja Rosdakarya, 2014, Cet. 2.

[4] Sutawi, "Keberhasilan Jepang Mengelola Kecerdasan Intelektual (IQ), Kecerdasan Emosional (EQ), dan Kecerdasan Spiritual (SQ)', Artikel dalam fardakhoirulroin. wordpress. com, Dipublikasikan 06/05/2010, https://farda khoirulroin. wordpress.com/ 2010/05/06/ keberhasilan- jepang-mengelola-kecerdasan-intelektual-iq-kecerdasan-emo sional-eqdan kecerdasan -spiritual-sq/

[5] A. Hasanah, " Ibnu Miskawaih : Pemikirannya Tentang Etika Dan Pendidikan", Diposkan 25 Juni 2011, http://fai-unismamalang.blogspot.com/2009/01/ibnu-miskawaih-pemikirannyatentang.html

[6] Rohmalina, Psikologi Agama. Jakarta: RajaGrafinda, 2015.

[7] M. Borba, Building Moral Intelligence, The Seven Essential Virtues That Teach Kids to do the Right Thing, Terj. Lina Jusuf, Membangun Kecerdasan Moral, Tujuh Kebajikan Utama agar Anak Bermoral Tinggi. Jakarta: Gramedia, 2008.

[8] E. John, "Upaya Meningkatkan Kedisiplinan Anak di Kelas melalui Cerita", Artikel dalam Jurnal Pendidikan Penabur Jakarta: BPK Penabur, Juni 2011, No.16/Tahun ke-10.

[9] F.P. Dermawan, "Mengembangkan Kecerdasan Emosional pada Anak", Makalah Disajikan pada Temu Ilmiah IPPI-IPS di Fakultas Psikologi Universitas Airlangga, Surabaya, 3 September 2007.

[10] A.A. Ginanjar, Spiritual Company Kecerdasan Spiritual Pembawa Sukses Kampium Bisnis Dunia, Jakarta: ARGA Pubsling, 2010.

[11] Paisal dan Susi Anggraini. "Pengaruh Kecerdasan Emosional dan Kecerdasan Spiritual terhadap Kinerja Karyawan Pada LBPP LIA-Lia Palembang", Artikel dalam Jurnal Ilmiah Orasi Bisnis, Palembang: Politeknik Negeri Sriwijaya, Edisi Ke-IV, Nopember 2010.

[12] R. Megawangi, Semua Berakar pada Karakter. Jakarta: Lembaga Penerbit UI, 2007, Cet. I.

[13] T. Kristiyani, Menghayati Makna Khidupan melalui Pembelajaran di Kelas dalam Proceeding Seminar Nasional, Yogyakarta: Universitas Sanata Darma, 2005, Cet. I.

[14] R. Megawangi, dkk, Pendidikan Holistik. Jakarta : Indonesia Heritage Foundation, 2013.

[15] R. Megawangi, dkk, Mencetak Generasi Kreatif. Jakarta: Indonesia Heritage Faundation, 2011, Cet. Ke-2. 